\title{
プラスチック基複合材料のリサイクルーIV. 自動車用プラスチック材料のリサイクル動向
}

\author{
長 島 泰 雄*
}

\section{1.は じめに}

科学技術の発展は, われわれの生活を豊かで快適なも のにする一方で, 地球環境に対し，さまざまな負荷をも たらしている. すなわち, 地球の温暖化, 大気污染や酸 性雨, オゾン層の破壞, 資源の枯渴, 廃棄物の増大等 が，樑刻な環境問題として論議され，対策が模索されて いる.

プラスチック類もまた, われわれの生活に不可欠の材 料として, 各分野できわめて有用な貢献をしているが, その優れた特性ゆえに, 使用済み材料の適切な処理/再 生を行い, 廃プラスチック類の環境への負荷を低減させ ることが，とくに強く求められている．日常生活におい て，また産業活動において，いわば動脈の役割を担ら自 動車にも，プラスチック材料は，多種多様に使用され， 自動車の軽量化，高機能化に寄与しているが，使用済み のプラスチック部品を適切に処理する新たな技術の開発 が大きな課題となっている.

本稿では, 自動車用プラスチック部品のリサイクルに 関する最近の動向，また，材料メーカ一の立場から実施 している、リサイクル研究の一端である自動車用バンパ 一の再生技術について紹介することとしたい。

\section{2. 自動車分野におけるプラスチックリサイクルの動向}

\section{1 全体状 況}

現在, 乗用車には, その全体重量の $7 \sim 8 \%$ のプラス チック材料が使用されており，その内容を図 1 に示す1). プラスチックリサイクルについては, 単一種類の材料 が安定的に供給されること, 技術的にリサイクルが容易 であることが，実施のための重要な条件であり，その意 味から, 熱可塑性樹脂であり, 使用量も比較的多い, ポ リプロピレン, ABS 樹脂等が， まずその対象としてと

\footnotetext{
* Yasuo NAGASHIMA : 宇部興産(侏樹脂ゴム事業本
} 部技術部（140 品川区東品川 2-3-11）
らえられることとなる.

一方, 日本における廃車処理の勧情は，図2 亿示寸通 りであり,一般的には, 解体業者が, エンジン, バッテ リ一, 触媒等の有用部品を取り外し, また, バンパー, フェンダー, ドアー, ミラー等についても, 再利用可能 と判断された場合は, それらを取り外し, その後シュレ ッディング業者が, 大型シュレッダーにより, 廃車本体 を破碀・裁断処理し，金属分を回収寸る．この過程で発 生する残迫であるシュレッダーダストは現在, 埋立て処 分されている.

この中に拈ける問題点, 課題としては, 以下の点があ げられる。

(1) 廃車台数の增加および自動車のプラスチック化の 進行に伴い, ダストの絶対量の増加, ダスト中のプ ラスチックの増加によるダスト嵩比重の低下がもた らされ, 廃棄物としての処理が困難な状態が生み出 されている. 廃車およびッュレッダーダストの発生 量推移を図 $3^{22}$ に，シュレッダーダストの成分分析 の一例を図 4 亿示す.

（2）このような状況への対策として，図2 の中にも示 されているが，まず，シュレッディング処理をする 前に，できるかぎり多くのプラスチック部品を取り 外すことが重要で, そのために, プラスチック部品 への材質表示, あるいは解体容易な部品の設計等が 行われている.ささら，ダストを燒却処理すること や，ダストを埋め立てるにしても，事前に減容化処 理を行らこと等が, 課题として提起されている.

\section{2 自動車用プラスチック部品のリサイクル}

自動車用プラスチック部品は, 大型品から小型品まで きわめて多数になるが、リサイクルの対象になりやすい 部品は, 当然のことながら, 比較的取り外しの容易な大 型部品といらことになる.このよらな状況を図 5 に示す が3), バンパーは, もっともリサイクルしやすい部品と いらことになる.さらに, 図 5 中に示されている, バン 


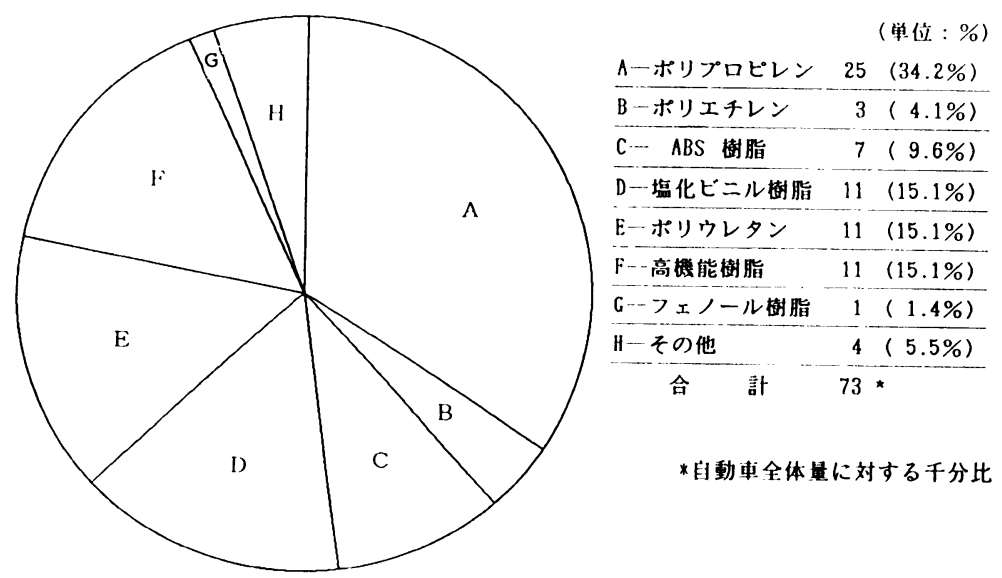

因 1 普通小型乗用車の樹脂材料構成

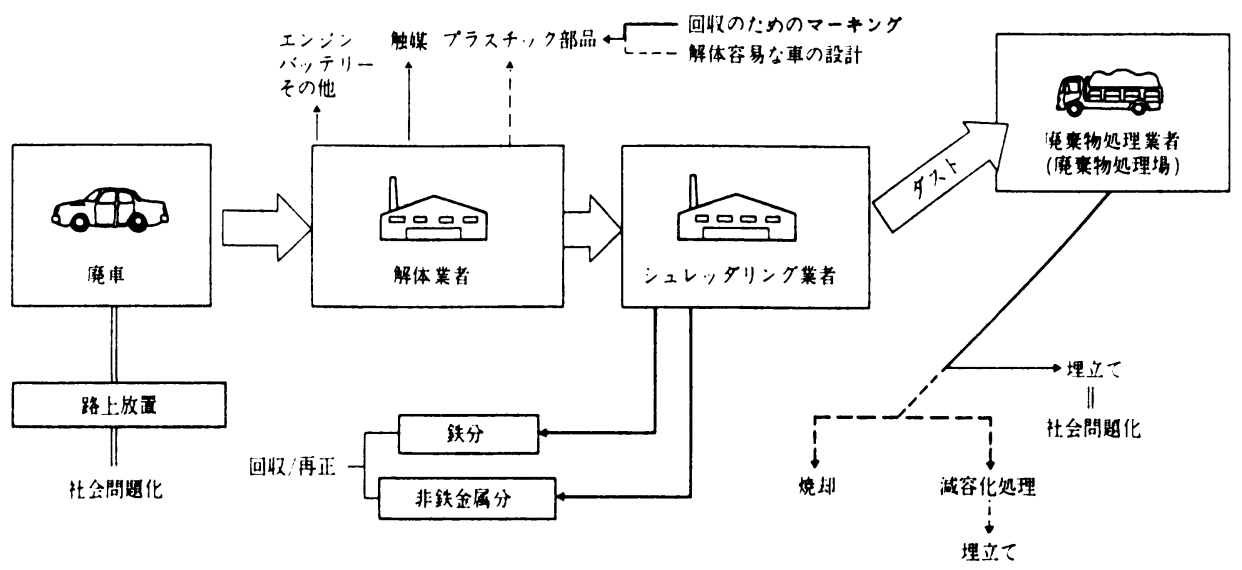

\section{——現行システム

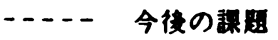

図 2 廃車処理システムの概要

パー, 燃料タンク, シート, インストルメントパネル, 4 部品の重量を合計すると, 全プラスチック部品の 3〜 4 割に相当し, これらの大型部品のリサイクルが，きわ めて効率的であることがわかる.

しかし、リサイクルがきわめてむずかしい部品は, 異 種材料の複合部品であり, 複合部品を分解して単一材料 からなる部品に分けることが，材料のリサイクル上好ま しいといえるが，このようなプロセスは一般的に大きな コストを要する. したがって, リサイクルが容易な要件 として, 大型部品, 取り外しの容易性のほかに, 複合性 の小さいことがあげられよう.

\section{3 リイクル関連法規制}

\subsection{1 日本の状況}

すでに,「再生資源の利用の促進に関する法律」（通称， リサイクル法）が施行されており，自動車関係プラスチ ック材料についても，リサイクルに関する指針が示され ている. この法律によれば, プラスチックにかかわる事 業者の責務として，以下の点が規定されている.

（1）再生資源として利用が可能なプラスチック製品の 開発，使用に努めること.

（2）再生資源としての利用が可能なプラスチック製品 の原材料としての利用を図ること、そのために，つ 


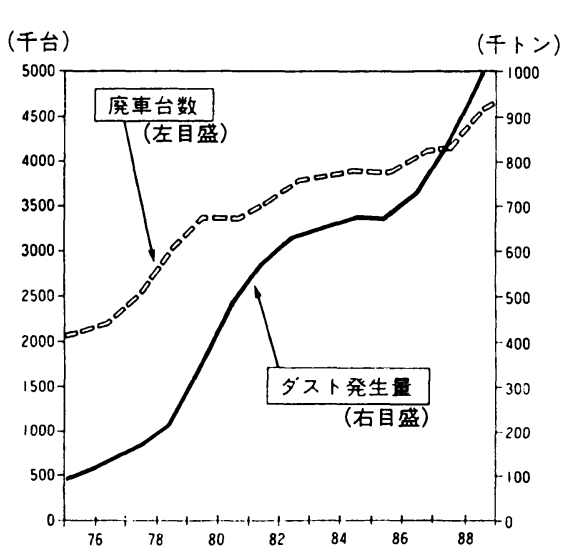

図3 廃車台数, ダスト発生量推移
ぎのような方策が求められている.
i ）分別回収を容易にする材質表示
ii）減容設備等の加工設備の整備
iii）再生資源の用途拻大

また，自動車製造事業者，修理業者が実施すべきリサ イクル関連の基準もさまざまな視点から定められてい る.

\subsection{2 ヨーロッパの状況}

とくに注目すべきは, ドィッの動向であり，現在，表 1 亿示す内容の法案の制定が検討されている.

この法案は, 自動車用プラスチック部品へのリサイク ル材使用を義務づけるものであり, 今後のリサイクル関 連の指針として，その成り行きが注目されている。

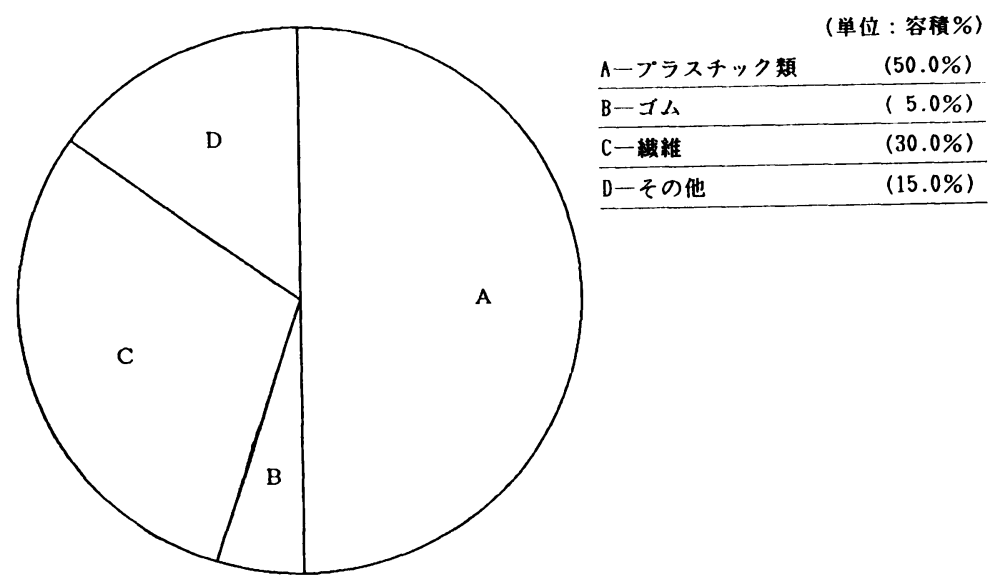

タスト発生量：廃車重量の䄪 $30 \%$

図4 廃車シュレッダーダスト構成物の一例

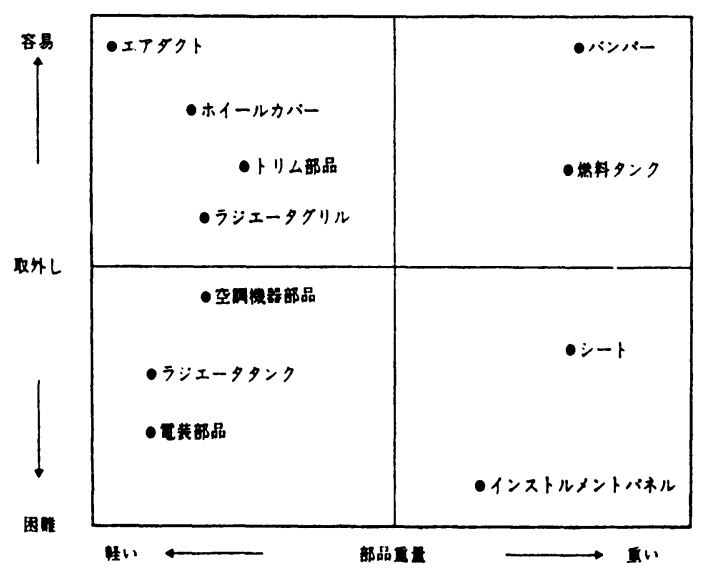

図 5 プラスチック部品の重量と解体のしやすさの関係 
表 1 自動車の解体処理に関する政令 (案) (ドイッ) 再生利用の目標

\begin{tabular}{lcc}
\hline \hline \multirow{2}{*}{ 素 } & \multicolumn{2}{c}{ 再生利用度 $($ 重量\%) } \\
\cline { 2 - 3 } & 1996 年 & 2000 年 \\
\hline 鉄 鋼 & 100 & 100 \\
非鉄金属 & 85 & 90 \\
プラスチック & $\underline{20}$ & $\underline{50}$ \\
タイヤ & 40 & 50 \\
他のエラストマー & 20 & 30 \\
ガラス & 30 & 50 \\
\hline
\end{tabular}

さらに，ヨーロッパでは, 上記の法案をも背景として リサイクルに関する異業種間の共同プロジェクトによる 研究も活発に行われており, 今後の日本におけるリサイ クル研究のあり方に一石を投じているといえよう。

\section{3. 自動車パンパーのリサイクル研究}

\section{1 現 況}

日本においては，自動車バンパーはポリプロピレン系 材料，またはポリウレタン系材料から製造されている. ポリプロピレンは熱可塑性樹脂であり，リサイクルしや すいことから，自動車メーカーおよび材料メーカーにお いて，ポリプロピレン系パンパーのリサイクル研究が積 極的に行われている.

なお，ポリウレタンバンパーについても，リサイクル 研究は行われているものの, ポリウレタンがリサイクル の困難な熱硬化性樹脂であるとの宿命を帯びており，将 来はポリプロピレン系パンパーが主流になるとの見方も 明らかにされている.

\section{2 バンパーの回収}

現在, 廃バンパーの発生源としてはつぎの四つのポイ ントがある.

（1）自動車メーカーの工場：工程内発生不良バンパー

(2) 自動車販売店 : 事故による交換バンパー

（3）自動車修理工場 : 同上

(4) 廃車

このらち, (1)については, 従来から自動車メーカー内 部でリサイクル検討がなされており，(4)については, 廃 車処理のルートが複雑なので, そのリサイクルの方策に ついてはまだ糸口が㨔めていない，一方，自動車販孛店 は自動車メ一カーの系列下にあるので, 事故により販売 店で新品バンパーと交換された不良バンパー（疵のつい たハンパー）は，ある特定自動車メーカーにより製造さ
れたものに限定され，その材質も比較的均一で，リサイ クル処理が容易ということになる.

したがって，バンパーリサイクルの第一ステップは, 上記(2)から発生するものを対象とし, 現在, 自動車メ一 カー, 材料メ一カー, 成形品メ一カ一協力の下に, リサ イクル研究が行われている.この場合の回収システムと しては，次のような流れが考えられている.

(1) ポリプロピレンバンパー，ポリウレタンバンパー の分別，金属部の除去

（2）トラックによる回収，集荷

（3）再生業者と樹脂メーカーによるポリプロピレンバ ンパーのリサイクル（洗浄, 粉研——成形材料—— 成形加工一一再生製品)

\section{3 回収バンパーの性能}

つぎに，回収されたポリプロピレンバンパーの性能に ついて説明しょう，日本では，大部分のバンパーが塗装 されているが，塗装バンパーおよび無塗装バンパーを長 期間走行した自動車から取り外し回収し，それらから性 能評価のためのテストピースを成形し，基本的な物性を 测定した結果も公表されている.

その結果, 無塗装バンパーから得られる材料は, バー ジン材料に比べ性能低下はわずかであることがわかり, 材料としてのリサイクル使用は可能と考兄られる．長期 間使用後の無塗装バンパーの表面および内部の変化の状 態を測定した結果が図 64)であるが，長期間使用により 変化するのは, 萃面層のごく一部だけであることから， バンパー全体としての性能にはほとんど影響しないとい える.

一方, 塗装バンパーから回収される材料は, その中に

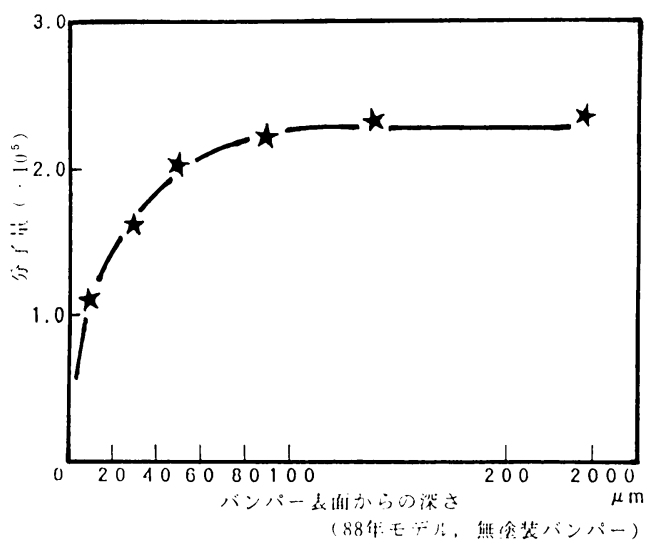

因 6 リサイクルハンパーの劣化（分子量対測定箇 所) 
表 2 塗装バンパーからのリサイクル材の性能

\begin{tabular}{lc}
\hline \multicolumn{1}{c}{ テスト項目 } & 物性保持率 $(\%)^{*}$ \\
\hline MFR & 89 \\
引張強度 $\left(\mathrm{kg} / \mathrm{cm}^{2}\right)$ & 96 \\
引張伸び $(\%)$ & 17 \\
曲げ弾性率 $\left(\mathrm{kg} / \mathrm{cm}^{2}\right)$ & 102 \\
アイゾット衝撃強度 $\left(-30^{\circ} \mathrm{C}\right)$ & 82 \\
$(\mathrm{~kg}-\mathrm{cm} / \mathrm{cm})$ & 22 \\
高速衝撃強度 $\left(-40^{\circ} \mathrm{C}\right)$ & \\
$(\mathrm{kg}-\mathrm{cm} / \mathrm{cm})$ & \\
\hline
\end{tabular}

*バージン材に対する保持率

塗装膜が混入し，それが異物として作用するために性能 が大きく低下する. 表 2 にその概要を示すが, 引張伸び, 衝撃強度の低下の著しいことが観察される.したがっ て, バージン材料に近い性能のリサイクル材料を得るた めには, バンパー上の塗装を, なんらかの方法で剥離・ 除去することが必要となる。一般的に，バンパー用塗料 は, アクリルーメラミン系, エステルーメラミン系あるい はウレタン系のものが使用されているが，之くに強固に ポリプロピレンに密着しているため, 剥離のためには特 殊な技術の開発が必要である.

以上から, バンパーのリサイクルについては, つぎの 二つの面から検討することが要求される.

(1) バンパー塗料を剥離・除去した高性能材料として のリサイクル

(2) バンパー塗料混入材料のリサイクル

このような流れをまとめて, 眓 7 に示した。

\section{4 バンパーの粉砕}

バンパーのリサイクルを垁施するに当たって，まずこ

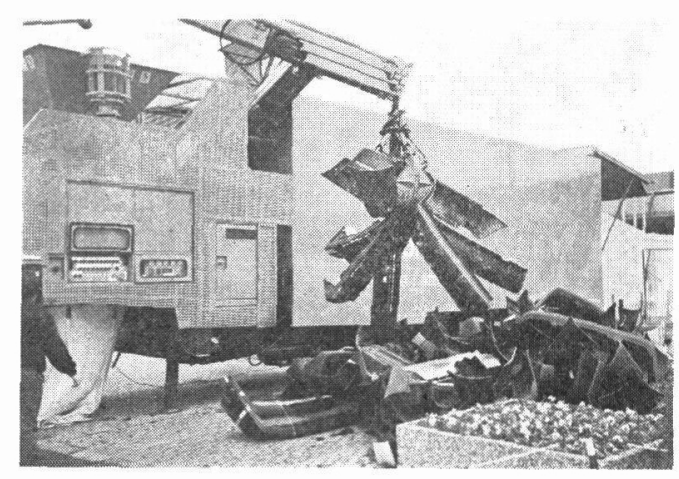

図 8 バンパー回収用粉砕機つき大型トレーラー

れを粉砕することが必要となる。粉砕については，とく に技術的に課題となる事項はなく，いかに経済的に粉砕 するかがポイントとなる.

ヨーロッパでは, 粉砕機つきの大型トレーラーにより バンパーを回収すると问時に，ただちにその場で粉砕し てしまらシステムも一部実施されており，このトレーラ 一の外観を図 $8^{5}$ に示寸.

\section{5 バンパーの再生技術}

塗装バンパーの塗装膜を剩離・除去することが重要な 意味をもつことを述べたが，バンパー塗装膜を実際に除 去する手法例については, 表 3 に示す.

バンバー塗装膜を剝離する技術自体は, 困難なるので はないが，重要なことはその経済性である。ここでは代 表的ないくつかの方法について説明すると同時に，興味 あるユニークな方法についても若干触れたい.

\subsection{1一般的方法}

(a) ショットブラスト法 適当な無機物または有機物粒子を高速でバンパー表 面に照射し，機械的に塗膜を剝離する.

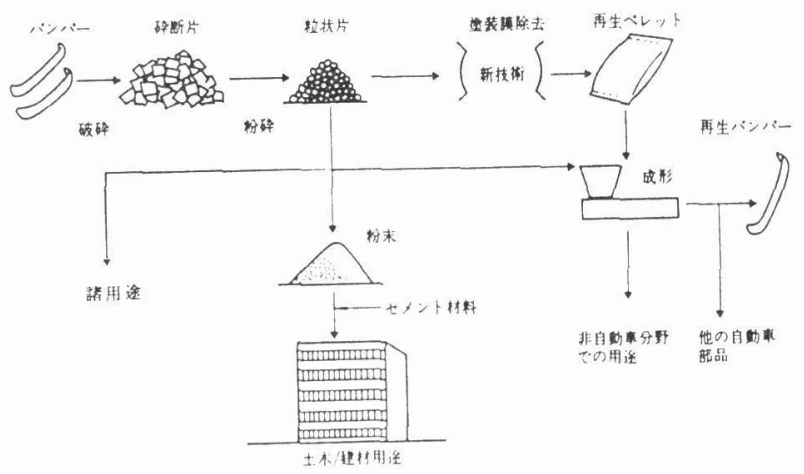

図 7 市場から回収される廃バンパーの再生 
表 3 パンパー塗装膜剝離技術

\begin{tabular}{|c|c|c|}
\hline 分 類 & 剝離技術 & 注 意 \\
\hline 機械的 & $\begin{array}{l}\text { ショットブラスト } \\
\text { 法 } \\
\text { 押出し/スクリー } \\
\text { ンメッシュ法 } \\
\text { 比重差分離法 }\end{array}$ & $\begin{array}{l}\text { 処理時間が長く, 複雑曲 } \\
\text { 面上の塗装剝離が困難. } \\
\text { メッシュ以下の大ささの } \\
\text { 塗膜が残存. } \\
\text { ハシンパーを微粉研する必 } \\
\text { 要がある. }\end{array}$ \\
\hline 物理的 & 溶剂膨潤法 & 溶剂除去に時間がかかる. \\
\hline 化学的 & $\begin{array}{l}\text { アルカリ液煮沸 } \\
\text { 酸性液煮沸 } \\
\text { 有機塩-アルュー } \\
\text { ルー水- }\end{array}$ & $\begin{array}{l}\text { 処理時間が長く, 中和工 } \\
\text { 程を要する. } \\
\text { 効果的であるが, 処理ュ } \\
\text { ストが高い. }\end{array}$ \\
\hline その他 & 振動圧縮法 & アインテクノロジー \\
\hline
\end{tabular}

(b) 押出し/スクリーンメッシュ法 不溶・不融の塗装膜を押出機フィルターで除去す る. 効果的なスクリーンチェンジャーを用いること が重要となる.

(c) 比重差分離法

バンパーの基材であるポリプロピレンと塗装膜の比 重の差を利用して塗装膜を分離する．比重分離を行 うためにはバンパーを微粉砕することが必要なの で，経済的な微粉砕技術の開発が必要となる.

これらの方法をまとめて，図 9 に示す。また，各種方 法により処理して得られたりサイクル材の性能を図 106) に示す．リサイクル材の機械的性質は比較的良好である がリサイクル材から得られたバンパーの表面性のチェ ック，あるいは塗装膜除去に要するコストの検討等が今 後の課題となろう.

\subsection{2 特 殊 法}

上記のほかにも，有機塩系溶剂7)や塩化メチレン系溶

1 押出し/スクリーン法

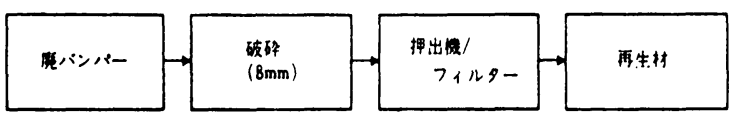

2 比重菨分篗法

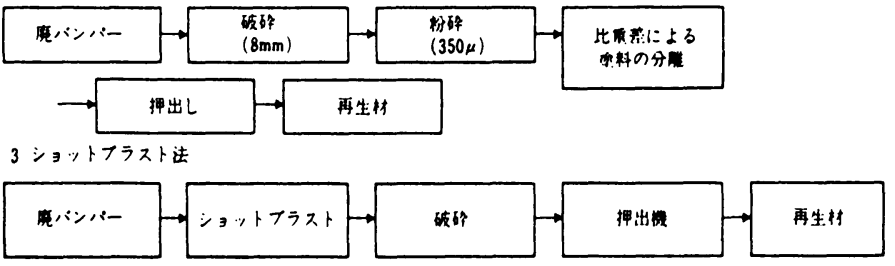

図9 PP パンパーのリサイクルプロセス（UBE 法）

(再生转/パージン材 $=1 / 9$ )

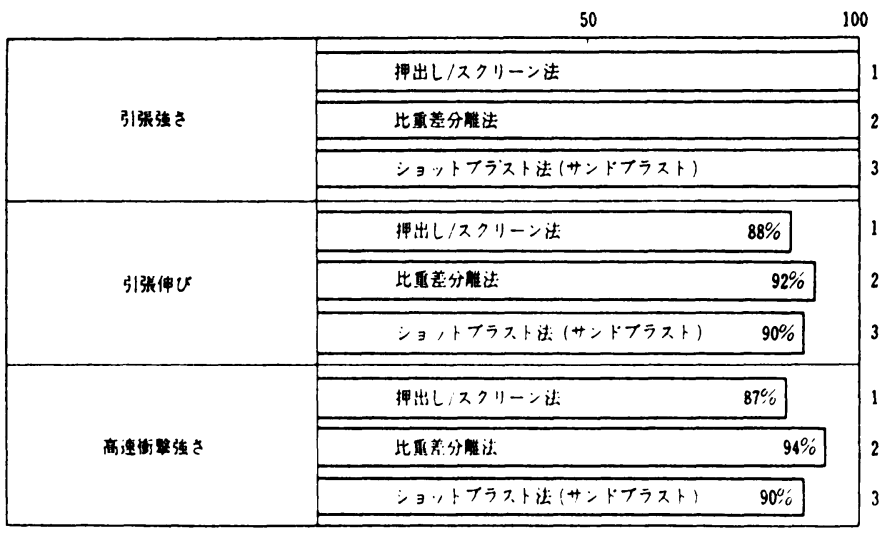

図 10 パンパーリサイクル材の物性 


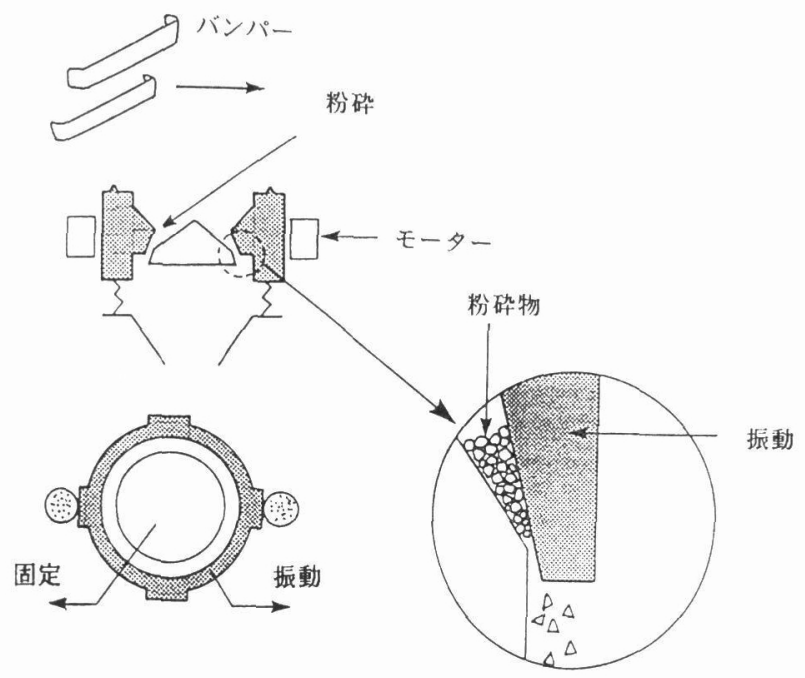

図 11 振動圧縮法による塗装パンパー処理

剂(8)により塗膜を除去する方法や, 特殊な機械的方法に よるものが紹介されているが，ここでは，後者について 簡単に触れておこう。

図 $11^{9)}$ は, 振動压縮法とよばれる方法の 概念を示し たもので，塗装バンパー粉砕品に，圧縮/せん断を与え ると, ポリプロピレン基材は塑性変形するが, 熱硬化性 塗装膜は変形せず，基材から洜離してくる．斬新なアイ デアに基づく新技術であり, 実用化へ向けての進展が期 待される.

\section{6 用途開発}

バンパーのリサイクルについては,「バンパーからバ ンパーへ」といらことが大きな目標となるが，そのため には, 前述した通り, 塗装膜を完全除去することが必要 となる. 一方, 塗装膜を部分的に除去した材料, あるい は，それが混入したままの材料については，その用途開 発が積極的に行われている.

バンパー材の自動車部品へのリサイクルについては, 今年 3 月開催された国際オートリサイクルショー '93 に 拝いても,トランクルームボード, シートバックボード, 各種内装材への応用等, さまざまな例が紹介され, また, ヨーロッパに拈いても, 無塗装バンパーをダッシュボー ドやドアポケットに再利用する例が紹介されている， ハ ンパー材を一般産業資材へリサイクルする場合，技術的 には, 自動車部品へのリサイクルよりも容易と考党ら れ，バンパー材を用いた搬送パレットはすでに実用化さ れている一例である.

\section{4. おわりに}

プラスチックのリサイクルについては, マテリアルリ サイクル (材料再生), ケミカルリサイクル (原料や油 類への変換), サーマルリサイクル(エネルギ一回収) と いった方法があり，垁情に応じてそれらを適用してゆく ことが重要であろう。同様に，自動車用プラスチックの リサイタルについても, まだ全体的な一つの方向が定め られているわけではなく, 今後, 関係者論議の下に, 有 効な取組み法に対する合意が形成されていくであろら. その流れの中にあって，個々の企業あるいは団体が，現 時点で実行可能な，例えばバンパーリサイクルのような 技術開発に取り組んでいくことがリサイクル潮流の加速 と収斂に大きな影響を及ぽすにちがいない。

\section{参考 文 献}

1）日本自動車工業会材料部品委員会資料.

2）日本自動車工業会他資料.

3）各自動車メーカー公表資料.

4) 宇部與産(搳怵資料.

5） K92フェア（ト゚イッ，デェセルドルフ), ハイモ ント社展示.

6) 宇部興産(侏技術資料.

7) 加藤 淳, 永山啓樹, 松谷久仁子：プラスチック エージ, 38, 9 (1992), 172.

8) 特開平 5-84746.

9）多田文明，嘉村信彦：プラスチックエージ，39, 4 (1993), 168 (アイン侏カタログ). 